\title{
Daya Saing Komoditas Kentang di Kabupaten Banjarnegara, Jawa Tengah Pendekatan Policy Analysis Matrix (PAM) \\ (The Competitiveness of Potato Commodities in Banjarnegara-Central Java, using Policy Analysis Matrix (PAM))
}

\author{
Doni Sahat Tua Manalu1), Suharno²), dan Netti Tinaprilla ${ }^{3)}$ \\ Departemen Agribisnis, Institut Pertanian Bogor \\ manaludoni@gmail.com
}

Diterima 29 April 2013/ Disetujui 13 Mei 2013

\begin{abstract}
Agricultural policy in any country causes intended and unintended impact on related sectors. Essentially, introduction of new commodity policy changes incentive structure to participating farmers of the sector. Policy analysis matrix (PAM) provides a framework and tools of analysis regarding the impact of policy change in simple but quantitative measure. This PAM analysis concerned mainly on the potato sector at sample area, Banjarnegara. The aim of this study was to analyze the impact of policies on the competitiveness of potatoes in Banjarnegara district, Central Java. Location of the research conducted in Banjarnegara district, the analysis method that used in this study are qualitative and quantitative analysis. Qualitative method is used to study the location decribe general description while quantitative method is used to analyze the competitiveness of the potato and the impact of government policies that analyzes the Policy Analysis Matrix. The analysis showed that potato farming in Central Java Banjarnegara district competitiveness, however, a policy that protects the price of potato output needs to be done so that the domestic potato can compete with the price of imported potatoes.

Keywords : Competitiveness, Potatoes, Policy Analysis Matrix (PAM)
\end{abstract}

\section{PENDAHULUAN}

Indonesia adalah negara agraris dan beriklim tropis, memiliki potensi alam yang mendukung pertumbuhan berbagai macam tanaman dan salah satunya adalah hortikultura. Komoditas hortikultura merupakan komoditas potensial yang mempunyai nilai ekonomi dan permintaan pasar yang tinggi. Pembangunan hortikultura juga meningkatkan nilai dan volume perdagangan internasional atas produk hortikultura nasional dan ketersediaan sumber pangan masyarakat.

Pembangunan hortikultura bertujuan untuk mendorong berkembangnya agribisnis hortikultura yang mampu menghasilkan produk hortikultura yang berdaya saing, mampu menyerap tenaga kerja, meningkatkan pendapatan petani dan pelaku usaha di bidang hortikultura, memperkuat perekonomian wilayah serta mendukung pertumbuhan pendapatan nasional. Oleh sebab itu diperlukan pembangunan hortikultura yang mengarah pada terciptanya pertanian yang efisien supaya mampu memenuhi permintaan domestik dan jika memungkinkan dapat mengekspor ke luar negeri. Indikator ekonomi makro berupa Produk Domestik Bruto (PDB) dapat digunakan sebagai salah satu alat ukur untuk mengetahui peranan dan kontribusi hortikultura terhadap pendapatan nasional.

Menurut data Direktorat Jenderal Hortikultura (2012), dari tahun 2008 sampai tahun 2009 nilai kontribusi sub sektor hortikultura terhadap PDB nasional mengalami 
peningkatan sebesar 2.47 persen. Namun pada tahun 2010, nilai PDB hortikultura mengalami penurunan sebesar 1.01 persen. Penurunan PDB hortikultura pada tahun 2010 disebabkan oleh penurunan jumlah produksi dari komoditas buah-buahan dan tanaman biofarmaka. Kemudian pada tahun 2011, nilai PDB hortikultura mengalami peningkatan kembali sebesar 1.30 persen.

Sementara BPS (2012) mencatat bahwa pada subsektor hortikultura perkembangan PDB selama kurun waktu 2008-2011, diikuti dengan penyerapan tenaga kerja yang relatif meningkat di subsektor tersebut. Pada tahun 2009 tenaga kerja yang dapat diserap sebanyak 2,95 juta orang, sementara tahun 2010 penyerapan tenaga kerja naik sebesar 3,00 juta orang dan tahun 2011 menjadi 3,32 juta orang. Pada tahun 2012 penyerapan tenaga kerja mengalami penurunan sebesar 3,10 juta orang. Proporsi ratarata kontribusi subsektor hortikultura dalam penyerapan tenaga kerja selama kurun waktu tahun 2009 - 2012 sebesar 8,25 persen dari keseluruhan pekerja di sektor pertanian. Melihat kontribusinya dalam PDB dan penyerapan tenaga kerja yang terjadi di subsektor hortikultura membuat pentingnya sub sektor ini dibangun.

Indonesia merupakan salah satu negara penghasil sayuran dan buah-buahan yang potensial. Berdasarkan data BPS tahun 2012, menunjukkan bahwa beberapa daerah di Indonesia yang berpotensi untuk memproduksi kentang seperti terdapat pada Gambar 1 yaitu Jawa Tengah, Jawa Barat, Jawa Timur, Sumatera Utara, dan wilayah lain.

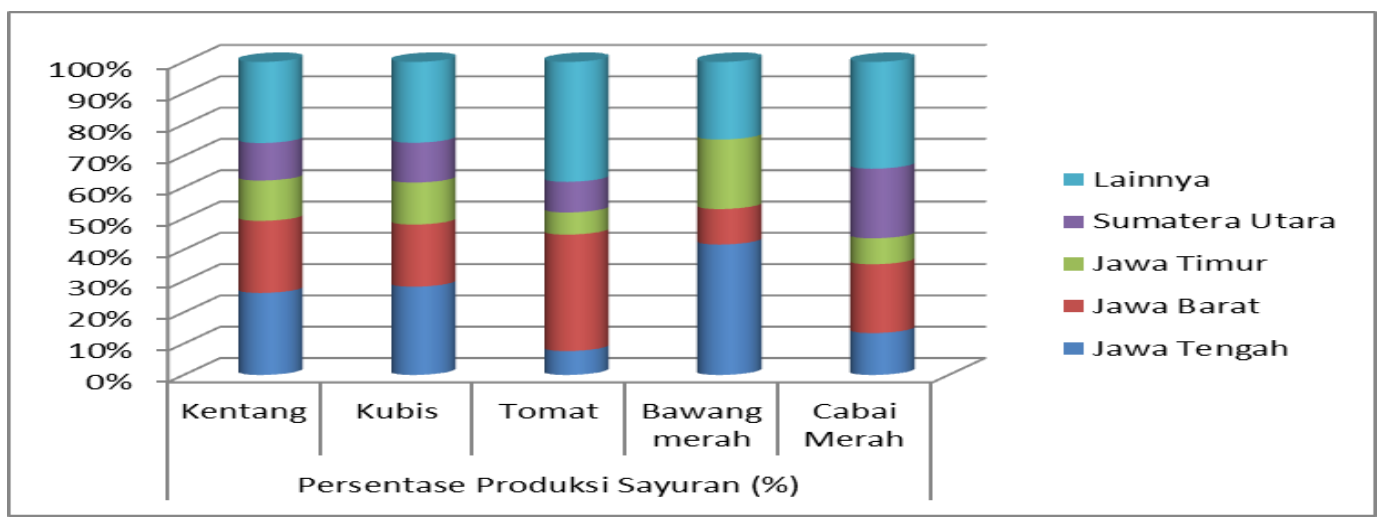

Gambar 1. Persentase Produksi Sayuran Potensi Menurut Provinsi di Indonesia pada Tahun 2011

Sumber BPS, 2012

Gambar 1 menunjukkan bahwa provinsi penghasil kentang pada tahun 2011 secara berturut-turut adalah provinsi Jawa Tengah, Jawa Barat, Sumatera Utara, dan Jawa Timur. Keempat Provinsi tersebut menyumbang sebesar 26.21 persen, 23.04 persen, 12.88 persen dan 8.95 persen. Total produksi yang dihasilkan keempat provinsi tersebut yaitu : 71.07 persen dan provinsi lainnya sebesar 28.93 persen. Berdasarkan data tersebut maka dapat diketahui bahwa provinsi Jawa Tengah adalah salah satu sentra produksi kentang di Indonesia.

Data nasional tahun 2006 menunjukkan bahwa produksi kentang dari tahun 2006 sampai 2008 berfluktuasi dan cenderung mengalami penurunan, meskipun pada tahun 2009 terjadi peningkatan produksi akan tetapi pada tahun 2010 kembali mengalami penurunan. Perkembangan produksi kubis, kentang, tomat, bawang merah, dan cabai besar dari tahun 2006 hingga tahun 2011 di Indonesia dapat dilihat pada Gambar 2 yang 
memperlihatkan pola serta data tentang kenaikan dan penurunan produksi setiap tahunnya.

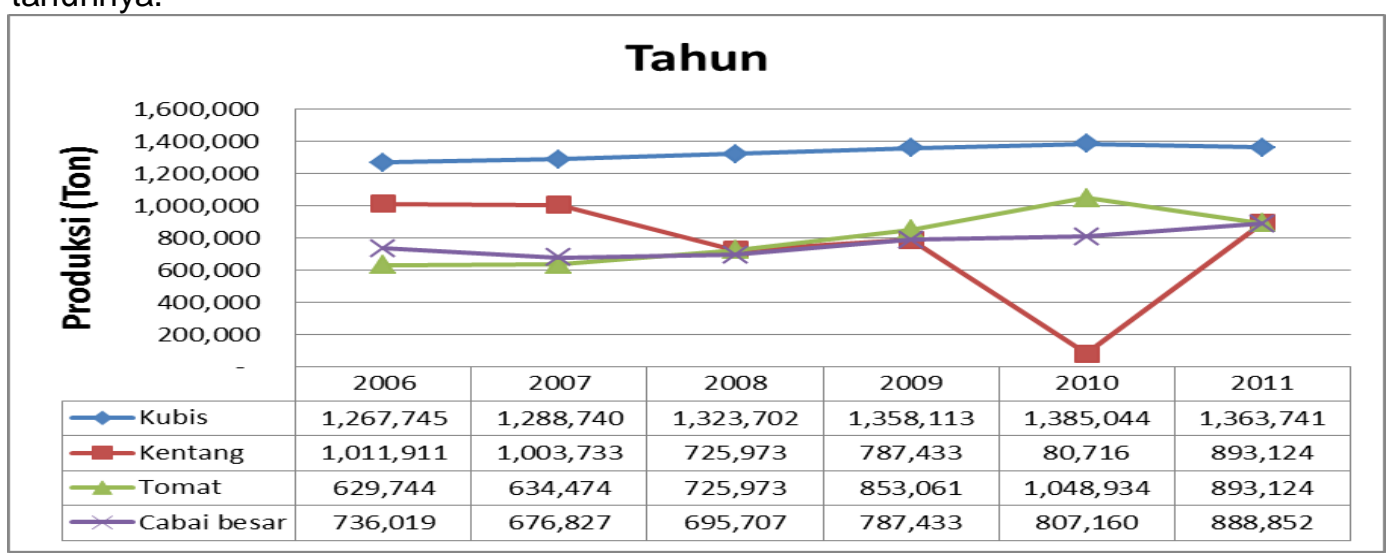

Gambar 2. Perkembangan Produksi Kubis, Kentang, Tomat, Bawang Merah, dan Cabai Besar dari Tahun 2006 hingga Tahun 2011 di Indonesia

Sumber BPS, 2012

Penurunan produksi yang sangat drastis pada tahun 2010 dikarenakan adanya impor kentang dari negara China dan Bangladesh. Adanya impor kentang tersebut menimbulkan persaingan dengan kentang lokal. Harga kentang impor ternyata lebih rendah jika dibandingkan dengan harga kentang lokal, hal ini sangat berpengaruh terhadap penurunan permintaan kentang lokal, kondisi tersebut menunjukkan bahwa kentang lokal tidak mampu bersaing dengan kentang impor.

Ketidakmampuan kentang lokal dalam bersaing perlu diketahui penyebabnya, oleh karena itu diperlukan penelitian yang mendukung khususnya di sentra produksi kentang agar dapat menggambarkan kondisi daya saing kentang lokal. Di Indonesia, provinsi Jawa Tengah adalah provinsi terbesar yang memproduksi kentang dan beberapa daerah di Jawa Tengah yang memproduksi kentang dapat dilihat pada Gambar 3.

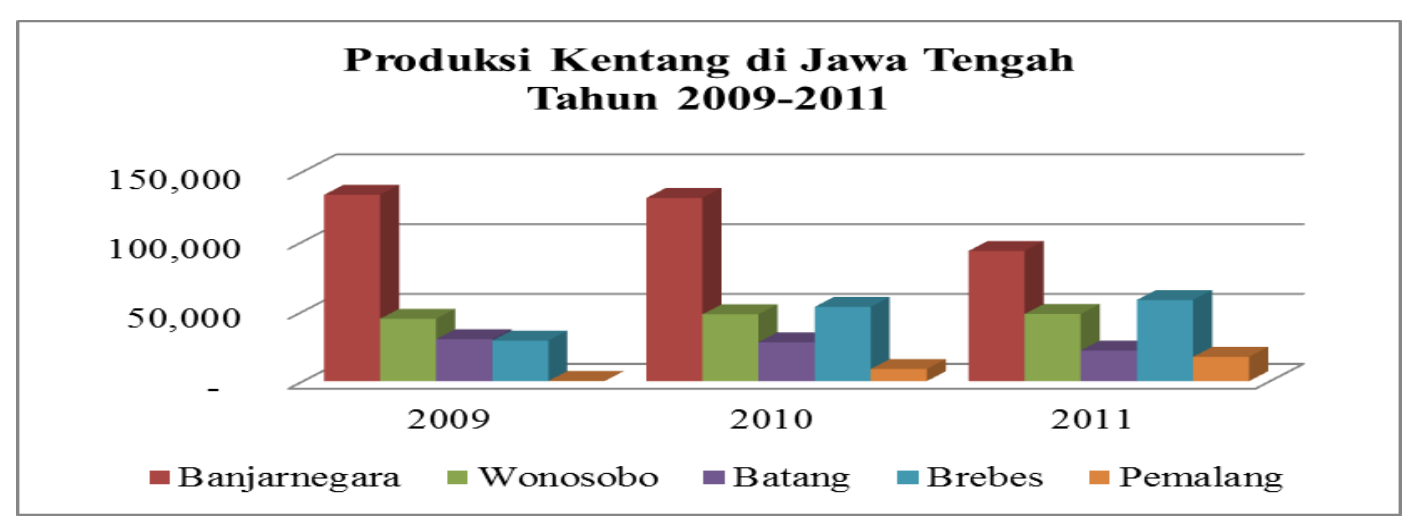

Gambar 3. Perkembangan Produksi Kentang di Jawa Tengah Tahun 2009-2011 Sumber BPS, 2012

Adanya arus globalisasi atau era perdagangan bebas akan mendorong para produsen kentang dalam negeri untuk dapat meningkatkan daya saing agar mampu bersaing dengan kentang dari negara lain sehingga dapat meningkatkan pendapatan petani, kondisi ini juga didukung pemerintah pusat dengan diberlakukannya penghentian 
sementara keran impor 13 jenis produk hortikultura, salah satunya komoditas kentang mulai bulan Januari sampai Juni 2013. Adanya Peraturan Menteri Keuangan No.241/PMK.011/2010 yang menaikkan pajak impor 5 persen atas produk bahan baku pertanian seperti, pupuk dan obat-obatan serta Peraturan Pemerintah nomor 7 tahun 2007 mengenai Pajak Pertambahan Nilai (PPN) sebesar 10 persen atas input-input produksi seperti peralatan, pupuk dan obat-obatan.

Akibat langsung yang terjadi karena adanya kebijakan pemerintah pada tahun 2010 tentang penetapan tarif impor kentang sebesar nol persen adalah volume impor kentang terus meningkat. Ketersediaan kentang Indonesia yang masih di bawah 5 $\mathrm{kg} / \mathrm{kapita} / \mathrm{tahun}$, membuat Indonesia mengalami penurunan khususnya dari sisi ekspor kentang segar. Tabel 2 menunjukkan bahwa volume ekspor kentang di Indonesia tahun 2004 hingga 2012 (triwulan 1) mengalami penurunan yang cukup besar hingga 15.022 ton sehingga nilai ekspornya menurun hingga 2.971.000 US\$, sedangkan volume impor kentang mengalami peningkatan yang tinggi sebesar 7.528 ton dalam 8 tahun terakhir sehingga nilai impor kentang segar mencapai peningkatan hingga 5.506.000 US\$.

Penurunan juga terlihat pada neraca volume sebesar -9.275 ton di tahun 2012 (triwulan 1). Di tahun yang sama, neraca nilai kentang segar menjadi -6.146 .000 US\$ sementara di tahun sebelumnya mencapai penurunan terbesar yaitu -43.833 .000 US\$ hal ini dapat lebih jelas dilihat pada Tabel 1.

Tabel 1 Volume, Nilai, dan Neraca Ekspor-Impor Kentang Segar di Indonesia Tahun 2004-2012

\begin{tabular}{|c|c|c|c|c|c|c|c|c|c|}
\hline \multirow[b]{2}{*}{ Keterangan } & \multicolumn{9}{|c|}{ Tahun } \\
\hline & 2004 & 2005 & 2006 & 2007 & 2008 & 2009 & 2010 & 2011 & $\begin{array}{l}2012 \\
\text { (Tw.1) }\end{array}$ \\
\hline $\begin{array}{l}\text { Volume } \\
\text { Ekspor (ton) }\end{array}$ & $\begin{array}{r}16 \\
422\end{array}$ & $\begin{array}{r}13 \\
644\end{array}$ & $\begin{array}{r}85 \\
922\end{array}$ & $\begin{array}{r}9 \\
652\end{array}$ & $\begin{array}{r}7 \\
958\end{array}$ & 6320 & 6771 & 5117 & 1400 \\
\hline $\begin{array}{l}\text { Volume } \\
\text { Impor (ton) }\end{array}$ & 3148 & 5031 & 4211 & $\begin{array}{r}5 \\
559\end{array}$ & $\begin{array}{r}5 \\
345\end{array}$ & $\begin{array}{r}11 \\
727\end{array}$ & $\begin{array}{r}24 \\
204\end{array}$ & $\begin{array}{r}78 \\
419\end{array}$ & $\begin{array}{r}10 \\
676\end{array}$ \\
\hline $\begin{array}{l}\text { Nilai Ekspor } \\
\text { (000 US\$) }\end{array}$ & 3547 & 3526 & 5917 & $\begin{array}{r}2 \\
855\end{array}$ & $\begin{array}{r}2 \\
340\end{array}$ & 2160 & 2426 & 2579 & 576 \\
\hline $\begin{array}{l}\text { Nilai Impor } \\
\text { (000 US\$) }\end{array}$ & 1217 & 2248 & 1959 & $\begin{array}{r}2 \\
686\end{array}$ & $\begin{array}{r}2 \\
880\end{array}$ & 6689 & $\begin{array}{r}14 \\
591\end{array}$ & $\begin{array}{r}46 \\
412\end{array}$ & 6723 \\
\hline $\begin{array}{l}\text { Neraca } \\
\text { Volume (ton) }\end{array}$ & $\begin{array}{r}13 \\
274\end{array}$ & 8612 & $\begin{array}{r}81 \\
712\end{array}$ & $\begin{array}{r}4 \\
093\end{array}$ & $\begin{array}{r}2 \\
612\end{array}$ & $\begin{array}{r}-5 \\
407\end{array}$ & $\begin{array}{l}-17 \\
433\end{array}$ & $\begin{array}{l}-73 \\
301\end{array}$ & $\begin{array}{r}-9 \\
275\end{array}$ \\
\hline $\begin{array}{l}\text { Neraca Nilai } \\
\text { (000 US\$) }\end{array}$ & 2330 & 1278 & 3959 & 169 & -540 & $\begin{array}{r}-4 \\
529\end{array}$ & $\begin{array}{l}-12 \\
165\end{array}$ & $\begin{array}{l}-43 \\
833\end{array}$ & $\begin{array}{r}-6 \\
146\end{array}$ \\
\hline
\end{tabular}

Sumber : BPS, 2012

Kebijakan (intervensi) pemerintah dengan melakukan impor kentang sebenarnya telah dilakukan secara sistematis dan terencana oleh pemerintah, akan tetapi hadirnya tindakan (kebijakan/intervensi) pemerintah mungkin saja mengakibatkan terjadinya distorsi (penyimpangan) pasar dan distorsi tersebut dapat membawa keuntungan atau kerugian bagi pelaku pasar tertentu baik konsumen maupun produsen, tergantung tujuan intervensi yang dilakukan. Kebijakan impor kentang yaitu penetapan tarif impor sebesar nol persen yang telah dilakukan pada tahun 2010 semula bertujuan untuk melindungi konsumen yang ada di dalam negeri, akan tetapi disisi lain justru dapat merugikan para petani (produsen) kentang di Indonesia dan khususnya di Kabupaten Banjarnegara, Jawa Tengah sebagai salah satu pusat produksi kentang di Indonesia.

Kondisi di pasar sebelum terjadinya peningkatan impor kentang adalah harga jual kentang lokal di daerah Banjarnegara rata-rata Rp 5.000 - Rp 6.000 per kg, setelah 
meningkatnya jumlah impor kentang yang masuk ke Indonesia maka harga kentang mengalami penurun sehingga harga rata-rata menjadi $\mathrm{Rp} 3.000$ - Rp 4.000 per $\mathrm{kg}$. Sementara harga rata-rata kentang impor yang dijual di pasar hanya Rp 2.500 - Rp 3.500 per kg (Dinas Pertanian, Perikanan dan Peternakan Kabupaten Banjarnegara, 2012). Hal ini menunjukkan kompetisi yang kuat antara produk kentang lokal dengan impor, sehingga perlu upaya yang dilakukan agar dapat meningkatkan daya saing kentang lokal.

Untuk membatasi impor kentang yang masuk ke dalam negeri pemerintah melalui kementerian perdagangan dan kementerian pertanian telah mengeluarkan kebijakan mengenai impor produk hortikultura, diatur melalui Peraturan Menteri Perdagangan Nomor 60 Tahun 2012 tentang Ketentuan Impor Produk Hortikultura dan Peraturan Menteri Pertanian Nomor 60 Tahun 2012 tentang ketentuan Rekomendasi Impor Produk Hortikultura (RIPH). Kedua beleid tersebut merupakan turunan dari Undang-Undang Nomor 13 Tahun 2010 tentang Hortikultura. Dari kebijakan tersebut diharapkan ada pengelolaan impor kentang yang tepat dan sesuai dengan kebutuhan dalam negeri, akan tetapi penerapan kebijakan tersebut perlu dievaluasi karena belum terlihat bagaimana dampaknya terhadap daya saing komoditas kentang di dalam negeri.

Aplikasi Policy Analysis Matrix yang digunakan pada penelitian ini adalah untuk melihat daya saing kentang di Kabupaten Banjarnegara, Jawa Tengah. Hal ini sangat dipengaruhi oleh kebijakan pemerintah yang berlaku tahun 2010 adanya ACFTA (AseanChina Free Trade Agreement) dan penetapan tarif impor nol persen sehingga tingkat keuntungan finansial dan ekonomi usahatani komoditas kentang di Kabupaten Banjarnegara, Jawa Tengah mengalami penurunan, serta perubahan kebijakan pemerintah pada tahun 2013 dengan melakukan penutupan keran impor bagi komoditi hortikultura salah satunya kentang dengan menutup pintu pelabuhan bagi produk impor.

Berdasarkan uraian di atas, maka dapat dirumuskan tujuan dari penelitian ini adalah:

1. Menganalisis dayasaing kentang di Kabupaten Banjarnegara, Jawa Tengah melalui pendekatan Policy Analisys Matrix (PAM).

2. Menganalisis dampak kebijakan pemerintah terhadap usahatani kentang di Kabupaten Banjarnegara, Jawa Tengah melalui pendekatan Policy Analysis Matrix (PAM).

\section{METODOLOGI}

\section{Lokasi dan Waktu}

Lokasi penelitian dilakukan di wilayah Kabupaten Banjarnegera. Pemilihan lokasi penelitian dilakukan secara purposive karena wilayah tersebut merupakan salah satu daerah sentra produksi kentang di Jawa Tengah, selanjutnya dipilih Kecamatan Batur karena memiliki luas lahan usahatani kentang terbesar di Kabupaten Banjarnegara. Kemudian untuk desa yang dipilih terdiri dari dua yaitu desa Batur dan desa Bakal karena memiliki luas panen dan produksi terbesar di kecamatan Batur. Pengumpulan data dilakukan pada bulan September-November 2013.

\section{Jenis dan Sumber Data}

Jenis data yang digunakan dalam penelitian ini meliputi data primer dan data sekunder. Pengumpulan data primer dilakukan melalui metode wawancara langsung, dan observasi lapang. Penentuan responden (petani contoh) untuk data primer dipilih secara purposive. Jumlah responden dalam penelitian ini adalah sebanyak 40 petani dengan kriteria pekerjaan utama petani tersebut adalah berusahatani kentang dan komposisi masing-masing 20 petani di setiap desa. Penentuan responden terhadap lembaga 
pemasaran, pedagang input pertanian, stake holder, pakar ahli di bidang kentang terkait penelitian ditentukan secara purposive dengan pertimbangan karena pihak tersebut dianggap paling mengetahui mengenai informasi yang diharapkan. Pelabuhan impor yang dijadikan acuan dalam penentuan harga perbatasan adalah pelabuhan Tanjung Priok, DKI Jakarta karena penerimaan kentang impor yang dikirim ke Banjarnegara berasal dari pelabuhan tersebut. Data sekunder diperoleh dari Badan Pusat Statistik RI, Kementerian Pertanian, Dinas Pertanian Banjarnegara, serta studi literatur.

\section{Metode Analisis Data}

Metode analisis data yang digunakan dalam penelitian ini adalah metode kualitatif dan metode kuantitatif. Metode kualitatif digunakan untuk mendeskripsikan gambaran umum lokasi penelitian, sedangkan metode kuantitatif yang digunakan untuk menganalisis daya saing kentang dan dampak kebijakan pemerintah yaitu analisis Policy Analysis Matrix.

\section{Policy Analysis Matrix}

Langkah-langkah yang dilakukan dalam analisis data penelitian terdiri atas beberapa tahap. Tahap pertama adalah penentuan input dan output usahatani kentang. Tahap kedua adalah pengidentifikasian input ke dalam komponen input tradable yaitu input yang diperdagangkan di pasar internasional baik diekspor maupun diimpor dan identifikasi input non tradable yaitu input yang dihasilkan di pasar domestik dan tidak diperdagangkan secara internasional. Ketiga, penentuan harga privat dan harga bayangan input dan output. Kemudian tabulasi dan analisis indikator-indikator yang dihasilkan tabel PAM. Data yang diperoleh diolah menggunakan perangkat lunak Microsoft Excel. Secara lengkap matrix analisis kebijakan [Policy Analysis Matrix (PAM)] dapat dilihat pada Tabel 2.

Tabel 2 Matrix Analisis Kebijakan [Policy Analysis Matrix (PAM)]

\begin{tabular}{|c|c|c|c|c|}
\hline \multirow{2}{*}{ Uraian } & \multirow{2}{*}{ Penerimaan Output } & \multicolumn{2}{|c|}{ Biaya Input } & \multirow{2}{*}{ Keuntungan } \\
\hline & & Tradable & Non Tradable & \\
\hline Harga Privat & $A$ & $\mathrm{~B}$ & $\mathrm{C}$ & $\mathrm{D}$ \\
\hline Harga Sosial & $E$ & $\mathrm{~F}$ & G & $\mathrm{H}$ \\
\hline Dampak Kebijakan & 1 & $\mathrm{~J}$ & $\mathrm{~K}$ & L \\
\hline
\end{tabular}

Sumber: Monke and Pearson (1989)

Keterangan :
A : Penerimaan Privat
G : Biaya Input non tradable Sosial
B : Biaya input Tradable Privat
$\mathrm{H}$ : Keuntungan Sosial
C : Biaya input non tradable Privat
I : Transfer Output
D : Keuntungan Privat
$\mathrm{J}:$ Transfer input Tradable
E : Penerimaan Sosial
$\mathrm{K}$ : Transfer Faktor
F : Biaya input tradable Sosial
L : Laba Bersih

Adapun indikator daya saing dari PAM yaitu:

\section{Analisis Daya Saing}

Keunggulan Kompetitif :

1. Keuntungan Privat (KP)

2. PCR (Rasio Biaya Privat)

$: D=A-(B+C)$

Keunggulan Komparatif :

1. Keuntungan Sosial (KS)

2. DRC (Rasio Biaya Sumberdaya Domestik)

$: P C R=C /(A-B)$

$: \mathrm{H}=\mathrm{E}-(\mathrm{F}+\mathrm{G})$

$: D R C=G /(E-F)$ 


\section{Analisis Dampak Kebijakan Pemerintah}

1. Kebijakan Output

a) Transfer Output (TO)

$: \mathrm{I}=\mathrm{A}-\mathrm{E}$

b) Koefisien Proteksi Output Nominal (NPCO)

$: \mathrm{NPCO}=\mathrm{A} / \mathrm{E}$

2. Kebijakan Input

a) Transfer Input (TI)

: J=B-F

b) Koefisien Proteksi Input Nominal (NPCl)

c) Transfer Faktor (TF)

: NPCL=B/F

$: \mathrm{K}=\mathrm{C}-\mathrm{G}$

3. Kebijakan Input-Output

a) Koefisien Proteksi Efektif (EPC)

b) Transfer Bersih (TB)

c) Koefisien Keuntungan (PC)

d) Rasio Subsidi bagi Produsen (SRP)

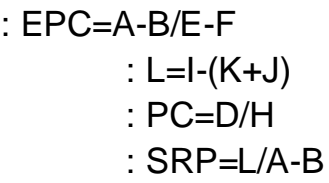

\section{Asumsi-Asumsi PAM}

Dengan menggunakan PAM sebagai alat analisis, suatu kegiatan ekonomi dapat dipandang dari dua sudut, yaitu: (a) sudut privat (private perspective) dan (b) sudut sosial (social perspective). Perbedaan sudut pandang tersebut membawa konsekuensi pada perbedaan perlakuan terhadap input dan output dari suatu kegiatan usaha dalam penggunaan harga-harganya. Beberapa asumsi dasar yang digunakan dalam analisis PAM adalah: (1) perhitungan berdasarkan harga privat untuk analisis finansial; (2) perhitungan berdasarkan harga sosial atau harga bayangan yang mewakili biaya imbangan sosial yang sesungguhnya untuk analisis ekonomi; (3) output bersifat tradable dan input dapat dipisahkan ke dalam tradable input dan domestic factor; (4) eksternalitas positif dan negatif dianggap saling meniadakan, dengan demikian dianggap nol.

\section{Harga Bayangan (Social Opportunity Cost)}

Harga bayangan adalah harga yang akan menghasilkan alokasi sumberdaya terbaik sehingga akan memberikan pendapatan nasional tertinggi (Pearson et al., 2005). Kondisi biaya imbangan sama dengan harga pasar akan sangat sulit ditemukan, maka untuk memperoleh nilai yang mendekati biaya imbangan atau harga sosial perlu dilakukan penyesuaian terhadap harga pasar yang berlaku (Gittinger, 1986). Alasan penggunaan harga bayangan adalah:

1. Harga bayangan tidak mencerminkan korbanan yang dikeluarkan jika sumberdaya tersebut dipakai untuk kegiatan lainnya.

2. Harga yang berlaku di pasar tidak menunjukkan apa yang sebenarnya diperoleh masyarakat melalui suatu produksi dari aktivitas tersebut.

Penentuan harga dasar yang terjadi belum tentu dapat dipakai langsung dalam analisis ekonomi karena tidak mencerminkan biaya imbangan sosial (opportunity cost). Suatu komoditas akan mempunyai biaya imbangan sama dengan biaya pasar jika berada pada pasar persaingan sempurna. Oleh karena itu, untuk memperoleh suatu nilai yang mendekati nilai biaya imbangan sosial diperlukan penyesuaian. Penyesuaian menggunakan acuan seperti yang dilakukan Gittinger (1986), penelitian terhadap pengusahaan komoditas menggunakan CIF (Cost Insurance and Freight) jika output dan input merupakan barang impor sedangkan penggunaaan FOB (Free on Board) jika output dan input merupakan barang ekspor. Selanjutnya harga batas tersebut dilakukan penyesuaian sampai di tingkat mana analisis dilakukan, karena dalam penelitian ini dilakukan analisis ditingkat petani, maka dilakukan penyesuaian hingga tingkat petani.

Pada penelitian ini, harga bayangan untuk input non tradable menggunakan biaya imbangan (opportunity cost), harga bayangan suku bunga modal (interest rate) 
menggunakan suku bungan riil yang dihitung dengan mengurangi suku bunga aktual dengan tingkat inflasi, tingkat suku bunga menggunakan tingkat suku bunga Bank Indonesia sebesar 4,48 \% per bulan atau 53,79\% per tahun dengan tingkat inflasi 8,30 $\%$ per tahun. Harga bayangan nilai tukar dengan menggunakan rata-rata nilai tukar (exchange rate) selama periode satu tahun besarnya diperoleh $\mathrm{Rp} .10 .706,830 / \mathrm{U} \$$, untuk tenaga kerja digunakan sama dengan nilai upah yang berlaku karena mekanisme pasar tenaga kerja pada komoditas kentang sangat kompetitif.

Harga beberapa input sosial yang diperoleh yaitu pupuk Urea, SP36, ZA diperoleh dengan menggunakan harga perbatasan dengan nilai Free On Board (FOB) pupuk Urea, SP36, ZA sebesar US $\$ 0.44$, US $\$ 0.23$, US $\$ 0.35$ per kilo gram. FOB digunakan karena Urea, SP36, ZA merupakan komoditas ekspor, kemudian dihitung nilai tukar bayangan pada tahun 2013 sebesar Rp 10.706,83, sehingga diperoleh FOB Indonesia dalam mata uang domestik berturut-turut $\mathrm{Rp} 4.759,04$, Rp 2.410,17, Rp 3.796,79 kemudian dihitung harga transportasi dan handling eksportir masing-masing sebesar $R p \quad 71,23$, ditambahkan dengan harga paritas ekspor pedagang besar dengan harga $\mathrm{Rp} 4.687,81$, $\mathrm{Rp} 2.338,94$, Rp 3.725,56 serta harga distribusi dan handling tingkat petani $\mathrm{Rp} 890,31$, Rp 662,01, Rp 2.200 maka diperoleh harga paritas ekspor di tingkat petani untuk pupuk Urea Rp 3.797,50, pupuk Sp-36 Rp 1.676,93 dan pupuk ZA Rp 1.525,56.

\section{Alokasi Komponen Biaya Domestik dan Asing}

Dalam asumsi PAM, input yang digunakan pada proses produksi dapat dipisahkan menjadi : (a) tradable goods, dan (b) domestic factor (non tradable goods). Input kategori pertama adalah input yang dapat diperdagangkan di pasar internasional sedangkan input kategori kedua adalah input yang tidak dapat diperdagangkan di pasar internasional, yang disebut dengan tradable goods adalah barang yang : (1) sekarang diekspor atau diimpor; (2) bersifat pengganti yang erat hubungannya dengan jenis lain yang diekspor atau diimpor; (3) komoditas selain di atas dan dilindungi oleh pemerintah, yang sebenarnya dapat diperdagangkan secara internasional. Menurut Pearson et.al. (1976) ada dua pendekatan yang digunakan untuk mengalokasikan biaya kedalam komponen domestik dan asing, yaitu pendekatan total dan pendekatan langsung.

Pendekatan langsung mengasumsikan bahwa seluruh biaya input tradable, baik diimpor maupun produksi domestik, dinilai sebagai komponen biaya asing. Pendekatan ini dipergunakan apabila tambahan permintaan input tradable baik barang yang diimpor maupun produksi domestik dapat dipenuhi dari perdagangan internasional. Kajian ini ditujukan untuk menganalisis daya saing atau keunggulan kompetitif dan komparatif komoditas kentang, maka digunakan pendekatan langsung.

\section{HASIL DAN PEMBAHASAN}

\section{Analisis Daya Saing Usahatani Kentang}

Usahatani kentang di Kabupaten Banjarnegara Jawa Tengah menguntungkan secara finasial maupun secara ekonomi (sosial) karena keuntungan privat (KP) dan keuntungan sosial (KS)-nya bernilai positif. Oleh karena itu, usahatani kentang di Kabupaten Banjarnegara Jawa Tengah layak untuk dijalankan baik secara finansial maupun ekonomi (Tabel 3). Keuntungan privat yang diperoleh lebih besar dibandingkan keuntungan sosial. Dari penerimaan finansial (private) dan ekonomi (sosial) Usahatani kentang di Kabupaten Banjarnegara Jawa Tengah diperoleh nilai divergensi (dampak kebijakan) yang bernilai positif. Hal ini disebabkan oleh harga privat kentang yang lebih tinggi dari harga sosialnya. 
Tabel 3 Policy Analysis Matrix (PAM) Usahatani Kentang di Kabupaten Banjar-negara, Jawa Tengah $(\mathrm{Rp} / \mathrm{Ha})$

\begin{tabular}{lrrrr}
\hline \multirow{2}{*}{ Uraian } & Penerimaan & \multicolumn{2}{c}{ Biaya } & \multirow{2}{*}{ Keuntungan } \\
\cline { 3 - 4 } & & Input Tradable & $\begin{array}{c}\text { Input Non } \\
\text { Tradable }\end{array}$ & \\
\hline Privat & $33.930 .658,84$ & $1.669 .649,89$ & $27.476 .981,22$ & $4.784 .027,72$ \\
Sosial & $28.902 .843,02$ & $982.751,16$ & $27.387 .680,26$ & $532.411,59$ \\
Dampak & & & & \\
Kebijakan & $5.027 .815,81$ & $686.898,72$ & $89.300,96$ & $4.251 .616,13$ \\
\hline
\end{tabular}

Berdasarkan Tabel 3 dapat dilihat bahwa usahatani kentang di Banjarnegara, Jawa Tengah menguntungkan tanpa adanya kebijakan apapun dengan jumlah keuntungan $\mathrm{Rp} 4.784 .027,726$. Harga privat kentang $\mathrm{Rp} 8.280$ sedangkan harga sosialnya sebesar $\mathrm{Rp} 6.711$, penyebabnya tidak ada kebijakan khusus yang memproteksi harga output kentang domestik. Kebijakan yang ada selama ini adalah subsidi pupuk dan subsidi BBM sebesar Rp 3.000 per liter untuk jenis premium yang akan mengurangi biaya transportasi pemasaran output tetapi tidak berpengaruh langsung untuk memproteksi harga output kentang domestik, sementara jika kebijakan penetapan tarif impor kentang menjadi nol persen seperti pada tahun 2010 diterapkan pada kondisi ini maka akan menyebabkan daya saing kentang domestik semakin rendah dibanding dengan kentang impor yang harganya lebih murah. Oleh karena itu, kebijakan terhadap output yang ada selama ini ada yaitu subsidi BBM sebenarnya sudah berpihak kepada petani, namun kebijakan tersebut belum mampu meningkatkan pendapatan petani dalam jumlah yang besar.

Kebijakan penutupan pintu impor bagi komoditas kentang di beberapa pelabuhan yang diterapkan pada tahun 2013, sebenarnya sangat baik dalam mendukung kentang domestik menjadi prioritas utama untuk dikonsumsi dalam negeri dan melakukan ekspor jika ada permintaan dari negara lain. Karena jika kentang dari luar negeri (negara pengimpor kentang) tetap dapat masuk ke Indonesia, maka harga kentang domestik dikhawatirkan masih belum mampu bersaing dengan harga kentang impor. Sementara itu kebijakan penutupan pintu impor bagi komoditas kentang di beberapa pelabuhan sudah mendukung petani kentang domestik, secara khusus petani kentang di Kabupaten Banjarnegara, Jawa Tengah. Selain kebijakan yang sudah ada, Pemerintah perlu membuat kebijakan baru terkait proteksi output kentang lokal guna meningkatkan daya saingnya sebagai komoditas dengan substitusi impor.

Selanjutnya, hasil dari tabel PAM yang telah diperoleh menunjukkan hasil analisis keunggulan komparatif dapat diukur dengan indikator Rasio Biaya Sumberdaya Domestik (DRC) dan Keuntungan Sosial (KS). Nilai dari indikator keunggulan kompetitif dan komparatif usahatani kentang di Kabupaten Banjarnegara dapat dilihat pada Tabel 4.

Analisis keunggulan kompetitif usahatani kentang di Kabupaten Banjarnegara dapat dilihat dari nilai Rasio Biaya Privat (PCR) dan Keuntungan Privat (KP). Nilai PCR dan KP dalam analisis keunggulan kompetitif merupakan indikator yang menunjukkan tingkat efisiensi penggunaan sumberdaya dan tingkat keuntungan usahatani kentang di Kabupaten Banjarnegara secara finansial (privat). Adapun nilai PCR usahatani kentang di Kabupaten Banjarnegara adalah sebesar 0,852, artinya usahatani kentang di Kabupaten Banjarnegara memiliki keunggulan kompetitif $(P C R<1)$, berdasarkan nilai PCR tersebut, usahatani kentang di Kabupaten Banjarnegara dapat dikatakan memiliki keunggulan kompetitif. 
Tabel 4 Nilai Keunggulan Kompetitif dan Komparatif Usahatani Kentang di Kabupaten Banjarnegara, Jawa Tengah

\begin{tabular}{lrr}
\hline \multicolumn{1}{c}{ Uraian } & Satuan & \multicolumn{1}{c}{ Nilai } \\
\hline Keunggulan Kompetitif & & \\
Keuntungan Privat & Rp/ha & $4.784 .027,726$ \\
Rasio Biaya Privat (PCR) & & 0,852 \\
Keunggulan Komparatif & $\mathrm{Rp} / \mathrm{ha}$ & \\
Keuntungan social & & $532.411,595$ \\
Rasio Biaya Sumberdaya Domestik (DRC) & & 0,981 \\
\hline
\end{tabular}

Selain itu, dapat diartikan juga bahwa usahatani kentang di Kabupaten Banjarnegara dapat membayar faktor domestiknya. Keunggulan kompetitif akan meningkat jika biaya faktor domestik dapat diminimumkan dan atau memaksimalkan nilai tambah output (Rooyen et al (2001), Pranoto (2011) dan Najarzadeh et al (2011). Menurut Pranoto (2011) dan Najarzadeh et al (2011), peningkatan nilai tambah output dapat ditingkatkan dengan penggunaan teknologi yang dapat menurunkan biaya per unit output.

Nilai DRC usahatani kentang di Kabupaten Banjarnegara Jawa Tengah yang dihasilkan oleh analisis PAM adalah 0.981 . artinya, bahwa setiap US $\$ 1$ yang dibutuhkan untuk impor kentang, jika diproduksi di Kabupaten Banjarnegara, Jawa Tengah membutuhkan biaya US $\$ 0.981$ sehingga terjadi penghematan biaya sebesar US $\$ 0.019$. Dengan demikian, meskipun penghematan yang terjadi tergolong dalam nilai yang kecil akan tetapi usahatani kentang di Kabupaten Banjarnegara menunjukkan penggunaan sumberdaya yang dapat dikategorikan efisien secara ekonomi (sosial) sehingga memiliki keunggulan komparatif dan menjadi produk substitusi impor. Semakin kecil nilai DRC $(\mathrm{DRC}<1)$ yang diperoleh, maka semakin tinggi keunggulan komparatif yang dimiliki. Hasil Penelitian ini juga sesuai dengan Najazadeh et al. (2011), Ugochukwu dan Ezedinma (2011), dan Basavaraj et al. (2013) yang mengatakan bahwa nilai $\mathrm{DRC}<1$ mengindikasikan suatu komoditas memiliki keunggulan komparatif.

Nilai DRC dan PCR dari analisis yang telah dilakukan dalam penelitian ini sama dengan hasil penelitian yang dilakukan oleh Novianto (2003) di desa Dieng Kecamatan Kejajar, Jawa Tengah yang menunjukkan bahwa nilai DRC dan PCR kentang lebih kecil dari satu sehingga dapat diartikan bahwa komoditas kentang tersebut berdaya saing (memiliki keunggulan komparatif dan kompetitif).

\section{Analisis Dampak Kebijakan Pemerintah terhadap Daya Saing Kentang di Kabupaten Banjarnegara, Jawa Tengah}

Dampak kebijakan pemerintah dapat dilihat dari analisis matrix PAM melalui beberapa indikator. Indikator-indikator dampak kebijakan pemerintah terhadap komoditas kentang di kabupaten Banjarnegara, Jawa Tengah terdiri dari dampak kebijakan terhadap output, input dan dampak kebijakan terhadap input-output terdapat pada Tabel 5. 
Tabel 5 Indikator-Indikator Dampak Kebijakan Pemerintah terhadap Usahatani Kentang di Kabupaten Banjarnegara, Jawa Tengah.

\begin{tabular}{lrr}
\hline \multicolumn{1}{c}{ Indikator } & Satuan & Nilai \\
\hline Dampak Kebijakan Terhadap Output & & \\
Transfer Output (TO) & $\mathrm{Rp} / \mathrm{ha}$ & 5.027 .816 \\
Koefisien Proteksi Output Nominal (NPCO) & & 1,174 \\
Dampak Kebijakan Terhadap Input & & \\
Transfer Input (TI) & $\mathrm{Rp} / \mathrm{ha}$ & $686.898,728$ \\
Transfer Faktor (TF) & $\mathrm{Rp} / \mathrm{ha}$ & $47.060,958$ \\
Koefisien Proteksi Input Nominal (NPCI) & & 1,699 \\
Dampak Kebijakan Terhadap Input-Output & & \\
Koefisien Proteksi Efektif (EPC) & $\mathrm{Rp} / \mathrm{ha}$ & 1,155 \\
Transfer Bersih (TB) & & $4.251 .616,131$ \\
Keofisien Keuntungan (PC) & 8,986 \\
Rasio Subsidi Produsen (SRP) & & 0,147 \\
\hline
\end{tabular}

\section{Dampak Kebijakan terhadap Output}

Nilai transfer output (TO) yang dihasilkan pada usahatani kentang Kabupaten Banjarnegara, Jawa Tengah adalah sebesar Rp 5.027.816 per hektar. Artinya harga output kentang di pasar domestik lebih tinggi dari harga internasionalnya. Hal ini dapat terlihat dari harga output pada struktur harga privat yang lebih rendah dibandingkan harga sosialnya yaitu $\mathrm{Rp} 8.280$ per kg (harga privat) dan Rp 6.684 per $\mathrm{kg}$ (harga sosial).

Pranoto (2011) menyatakan bahwa nilai TO negatif dapat diinterprestasikan bahwa harga produk ditingkat petani atau domestik lebih rendah dari harga di pasar internasional. Hal ini berarti harga jual kentang domestik lebih mahal dari harga di pasar internasional. Pada penelitian ini diperoleh TO positif artinya meskipun ada kebijakan Pemerintah yang melindungi secara langsung output kentang akan tetapi belum dapat membuat harga kentang domestik menjadi lebih rendah dari harga kentang impor.

Hasil analisis menunjukkan bahwa nilai NPCO usahatani kentang di Kabupaten Banjarnegara, Jawa Tengah sebesar 1,174 (NPCO>1), artinya harga domestik untuk output kentang lebih tinggi dari harga output internasionalnya sehingga terdapat proteksi yang dilakukan oleh Pemerintah terhadap outputnya, proteksi yang dilakukan dalam hal ini adalah dengan menutup pintu pelabuhan untuk impor kentang yang berasal dari negara lain. Kebijakan yang dilakukan untuk memproteksi output tersebut ternyata dapat menguntungkan produsen kentang domestik karena harga jual kentang dapat lebih tinggi. Hasil penelitian ini berbeda dengan penelitian Novianto (2003) yang menunjukkan nilai NPCO $<1$ karena pada tahun 2003 harga kentang di domestik masih lebih rendah dari harga dunia dan belum ada kebijakan penutupan pintu pelabuhan untuk impor kentang.

Kondisi kebijakan yang mendukung tersebut sebenarnya belum menjamin pendapatan produsen kentang lokal meningkat, karena kondisi pasar domestik juga kecenderungan tidak berpihak pada produsen kentang lokal karena banyaknya pihak yang bermain di pasar seperti pedagang pengumpul (tengkulak), pedagang besar yang dapat menyebabkan lemahnya posisi tawar petani. Menurut Novianto (2003) serta Ugochukwu dan Ezedinma (2011), pengurangan penerimaan petani juga dapat diakibatkan oleh lemahnya posisi tawar petani dalam menentukan harga. Harga jual kentang di Kabupaten Banjarnegara kecenderungan ditentukan oleh pedagang pengumpul sehingga posisi petani dalam penentuan harga kentang menjadi lemah.

\section{Dampak Kebijakan terhadap Input}

Transfer Input merupakan selisih antara biaya input berdasarkan harga privat dan harga sosial. Berdasarkan hasil analisis, nilai TI yang diperoleh adalah positif atau 
lebih besar dari nol yaitu sebesar Rp 686.898,728 per hektar. Hal ini berarti harga sosial input asing lebih rendah, akibatnya produsen tidak perlu membayar input lebih mahal.

Nilai TF kentang di Kabupaten Banjarnegara, Jawa Tengah bernilai positif, yaitu sebesar Rp 47.060.958 per hektar. Nilai tersebut menunjukkan bahwa terdapat implisit subsidi positif pada input non tradable (faktor domestik) dari Pemerintah yaitu subsidi BBM sebesar Rp 3.000 per liter untuk jenis premium dan juga subsidi. Oleh karena itu, kebijakan tersebut efektif untuk tetap dilaksanakan.

Untuk menunjukkan tingkat proteksi (kebijakan) yang dibebankan pemerintah pada input tradable apabila dibandingkan tanpa adanya kebijakan pemerintah, dapat dilihat dari besarnya nilai Koefisien Proteksi Input Nominal (NPCl). Hasil analisis NPCI usahatani kentang di Kabupaten Banjarnegara, Jawa Tengah bernilai lebih besar dari satu yaitu sebesar 1,699. Nilai ini menunjukkan bahwa terdapat proteksi terhadap produsen input asing tradable, yang menyebabkan sektor yang menggunakan input tersebut akan dirugikan dengan tingginya biaya produksi karena petani membeli input tradable lebih mahal dari harga dunia akibat adanya pajak impor sebesar 5 persen dan PPN sebesar 10 persen pada input tradable Novianto (2003) dan (Pranoto 2011).

\section{Dampak Kebijakan terhadap Input dan Output}

Effective Protection Coefficient (EPC) menggambarkan sejauh mana kebijakan Pemerintah bersifat melindungi atau menghambat produksi domestik. Hasil analisis menunjukkan bahwa nilai EPC usahatani kentang di Kabupaten Banjarnegara, Jawa Tengah lebih besar dari satu atau sebesar 1,155. Hal ini berarti bahwa kebijakan pemerintah terhadap input-output yang berlaku sudah efektif melindungi petani kentang di Kabupaten Banjarnegara, Jawa Tengah. Berbeda dengan Novianto (2003) yang menyatakan bahwa kondisi kentang di desa Dieng memiliki nilai EPC $<1$ karena saat itu tidak ada kebijakan yang dilakukan pemerintah yang secara langsung melindungi input maupun output.

Nilai TB di lokasi penelitian bernilai lebih besar dari satu (positif) yaitu sebesar Rp 4.251.616,131. nilai ini menunjukkan adanya tambahan surplus produsen yang disebabkan oleh kebijakan pemerintah yang dilakukan pada input-output kentang di Kabupaten Banjarnegara, Jawa Tengah. Nilai PC yang dihasilkan dalam penelitian ini adalah kurang dari satu yaitu sebesar 8.986. nilai tersebut menunjukkan bahwa kebijakan pemerintah yang mengakibatkan keuntungan yang diterima produsen lebih besar jika dibandingkan tanpa adanya kebijakan. Subsidy Ratio to Producer (SRP) menunjukkan tingkat penambahan dan pengurangan penerimaan karena adanya kebijkan Pemerintah. SRP di lokasi penelitian bernilai positif yaitu 0,147 yang berarti bahwa kebijakan pemerintah yang berlaku selama ini menyebabkan produsen (petani) kentang di Kabupaten Banjarnegara Jawa Tengah mengeluarkan biaya lebih rendah dari biaya sosial untuk berproduksi.

Secara keseluruhan dapat disimpulkan bahwa kebijakan pemerintah terhadap input-output yang ada saat ini sudah melindungi petani kentang di Kabupaten Banjarnegara, Jawa Tengah. Subsidi pupuk dan juga penutupan pintu pelabuhan untuk impor kentang yang dilakukan ternyata dapat melindungi produsen kentang dalam negeri.

\section{Simpulan}

\section{SIMPULAN DAN SARAN}

1. Usahatani komoditas kentang di Kabupaten Banjarnegara, Jawa Tengah menguntungkan secara finansial dan ekonomi dengan keuntungan finansial sebesar Rp4.784.027,72 dan keuntungan ekonomi sebesar Rp 532.411,59. 
2. Usahatani komoditas kentang di Kabupaten Banjarnegara, Jawa Tengah memiliki daya saing baik keunggulan kompetitif maupun keunggulan komparatif karena efisien secara produksi dengan nilai PCR dan DRC lebih kecil dari satu yaitu PCR sebesar 0,852 dan DRC sebesar 0,981.

3. Kebijakan pemerintah terhadap input serta terhadap output yang terjadi saat ini sudah mendukung peningkatan daya saing usahatani komoditas kentang.

\section{Saran}

1. Pemerintah tetap memproteksi impor kentang yang masuk ke Indonesia, dengan menutup pintu pelabuhan untuk impor kentang atau dengan menerapkan sistem kuota dan tarif agar dapat meningkatkan daya saing agribisnis kentang di Kabupaten Banjarnegara, Jawa Tengah melalui keunggulan kompetitif dan keunggulan komparatif secara khusus sebagai produk substitusi impor.

2. Pemerintah perlu membuat kebijakan khusus untuk melindungi petani dalam hal menjaga kestabilan harga output kentang (subsidi harga output) dan juga menjaga kestabilan harga input.

3. Bagi pihak yang tertarik untuk melakukan penelitian selanjutnya diharapkan dapat menganalisis efisiensi dan faktor-faktor yang mempengaruhi produksi usahatani kentang di Kabupaten Banjarnegara, Jawa Tengah serta topik-topik lainnya dalam rangka peningkatan daya saing kentang.

\section{DAFTAR PUSTAKA}

[BPS] Badan Pusat Statistik. 2012. Statistik Tanaman Buah-buahan dan Sayuran Tahunan. Jakarta : Badan Pusat Statistik.

[BPS] Badan Pusat Statistik. 2013. Statistik Perdagangan Luar Negeri (Ekspor dan Impor). Jakarta : Badan Pusat Statistik.

Basavaraj G, Rao PP, Achoth L, Reddy CR,. 2013. Assesing Competitiveness of Sweet Sorghum for Ethanol Production: A Policy Analysis Matrix Approach. Agricultural Economics Research Review. http://ageconsearch.umn.edu/handle/152074. $(30 / 11 / 13)$.

Gittinger, J.P. 1986. Analisa Ekonomi Proyek-Proyek Pertanian. Terjemahan. Edisi Kedua. UI-Press dan John Hopkins, Jakarta.

Kapaj AM, Kapaj I, Halbrendt CC, Totojani O. 2010. Assesing the Comparative Advantage of Albanian Olive Oil Production. International Food Agribusi-ness Management Review. International Food Agribusiness Management Association (IAMA). http://ageconsearch.umn.edu/items-. (30/11/13).

Monke AE, Pearson SR. 1989. Policy Analysis Matrix for Agricultural Development. New York (US) : Cornell University Press. Najarzadeh R, Rezagholizadeh M, Saghaian S, Reed M, Aghaie M. 2011. The Impact of Trade Liberalization on Persian Rugs: A Policy Analysis Matrix Approach. Journal of food Distribution Research 42. http://ageconsearch.umn.edu/handle/139335. (30/11/13).

Novianto, T. 2003. Analisis Dampak Kebijakan Pemerintah Terhadap Daya Saing Komoditas Unggulan Sayuran. Tesis. Pascasarjana : Institut Pertanian Bogor. Bogor.

Oguntade, Adegboyega. 2011. Assessment of Protection and Comparatif Advantage in Rice Processing in Nigeria. Jurnal Departement of Agricultural and Extension, Federal University of Technology, Akure, Nigeria. 1(2): 50-88. http://ageconsearch.umn.edu/handle/139335. (30/11/13).

Pearson S,C, S. Bahri. 2005. Aplikasi Policy Analysis Matrix pada Pertanian Indonesia. Terjemahan. Yayasan Obor Indonesia, Jakarta. 
Pranoto, SY. 2011. Dampak Kebijakan Pemerintah terhadap Keuntungan dan Daya Saing Lada Putih (Muntok White Paper) di Provinsi Bangka Belitung tesis. Pascasarjana: Institut Pertanian Bogor. Bogor.

Rooyen IM, J.F. Kirsten, C.J. Van Rooyen. 2001. The Competitiveness of the South African and Australian Flower Industries: an Application of Three Methodologies. Paper presented at the 45th Annual Conference of the Australian Agricultural and Resource Economics Society, January 23 to 25, 2001, Adelaide, South Australia. http://ageconsearch.umn.edu/handle/143498. (30/11/13).

Ugochukwu Al, Ezedinma Cl. 2011. Intensification of Rice Production systems in southeastern Nigeria: A Policy Analysis Matrix Approach. International Journal of Agricultural Manajement and Development (IJAMAD). http://ageconsearch.umn.edu/handle/143498.(30/11/13). 